\title{
多孔質動圧スラスト・ラジアル複合軸受における 非定常時潤滑特性の実験的研究*
}

\section{（複合軸受における軸起動時軸振れ振幅時刻歴へのクリアランス変化の影響について）}

\author{
大塚 茂 ${ }^{* 1}$, 矢壁 正樹 ${ }^{* 1}$ ，権田 岳*1，山田 博之*2
Experimental Study on the Lubrication Characteristics of Thrust-Radial Coupled Porous Bearings with Hydrodynamic Shape Forming under Shaft Unsteady Condition of Shaft on Thrust-Radial Coupled Porous Bearings under Shaft Starting Condition) \\ (Examination for the Influence of Diametral Clearance Change to the Time History Waveform \\ Shigeru OHTSUKA ${ }^{* 1}$, Masaki YAKABE, Takeshi GONDA and Hiroyuki YAMADA \\ ${ }^{* 1}$ Department of Mechanical Engineering, Yonago National College of Technology, \\ 4448 Hikona-cho, Yonago-shi, Tottori, 683-8502, Japan. \\ This study proposes the combinations of some hydrodynamic shapes formed on the end or the annular surface of oil \\ impregnated sintered porous bearing as a DC spindle motor's bearing system. Hydro Wave Bearing or Pump In as a thrust \\ hydrodynamic shape, and Herring Bone ( I \& II), Three Lobed Type or Sleeve as a radial hydrodynamic shape were \\ proposed, and the total of eight kinds of combinations were produced as thrust-radial coupled bearing. It examines to \\ optimize the hydrodynamic shape combination experimentally as thrust-radial coupled bearing by measuring the lubrication \\ characteristics. This research report is especially referred to the experimental examination for Settling Time, Lissajous Curve \\ diagram or Shaft Whirling by measuring the Time History Waveform of shaft such as the lubrication characteristics under \\ unsteady shaft starting condition. Furthermore this report examines the influence of diametral clearance change to the \\ lubrication characteristics such as above mentioned by measuring the Time History Waveform of shaft under shaft starting \\ condition.
}

Key Words : Thrust-Radial Coupled Bearing, Porous Bearing, Hydrodynamic Shape Forming, Shaft Unsteady Condition, Lubrication Characteristics, Diametral Clearance Change

\section{1. 緒言}

現在，情報家電ならびに PC 周辺機器である HDD，DVD・BD ドライブなどの駆動系として広く使用されてい る DC 小形スピンドルモータは，メディア容量の増加やトラックピッチの微細化，およびユビキタスネットワー ク社会へ向けたモバイル化などへの対応が喫緊の課題となっている. これらの要望を満足するためには，モータ 自身の高速, 高精度（主にNRRO やRRO といった軸振れ回り精度の向上，高信頼性，小型軽量などを低コスト とともに達成する必要がある。このような背景のもと，近年では上記モータの軸受機構に安価で量産性に富んだ 多孔質体である $\mathrm{Fe}-\mathrm{Cu}$ 系焼結含油軸受を使用した例がよく見受けられる.

著者らはこの焼結含油軸受の端面および内周面に，気孔調整層と動圧形状を形成し，メディア回転時の軸方向 および径方向の荷重を支承するスラスト・ラジアル複合軸受（以降，複合軸受）の検討をこれまで実験的に行っ てきた，複合軸受の潤滑特性には，摩擦トルク，軸受温度上昇值，軸振れ量，定量的浮上性としての接触回数， および而久性試験における含浸油消費率などを測定している。そして実験結果より，省エネルギ一化，および高 精度化に対応する軸振れ量の抑制，ならびに重要課題である軸受の長寿命化などにつながる良好な潤滑状態を長

\footnotetext{
* 原稿受付 2012 年 7 月 9 日

*1 正員, 国立米子工業高等専門学校（一683-8502 鳥取県米子市彦名町 4448）

*2 学生員, 長岡技術科学大学 工学研究科 機械創造工学専攻 （广940-2188 新潟県長岡市上富岡町 1603-1）

E-mail: otsuka@yonago-k.ac.jp
} 
期的に達成する動圧形状の仕様やその組合せの特定を試みてきた ${ }^{(1) \sim(3)}$.

一方，他の多孔質複合軸受に関する研究の多くは，例えば古林ら ${ }^{(4)}$ のようシミュレーション解析により負荷 容量，軸受剛性などの潤滑特性を検討したものが主であり，実験による研究報告例を比較対象として加えてあっ ても，摺動面に十分な油膜が形成された一定回転数における定常状態での潤滑特性評価がほとんどであった.

そこで本研究では, 特に携帯情報端末に代表されるモバイル環境にて頻繁に発生するモータの起動・停止を想 定し，従来の定常状態における軸受剛性・ダンパ係数などを算出し，回転軸の運動方程式と連成して解くシミュ レーション解析では困難な非定常状態における回転軸の挙動解明を実験的に行っていく. 具体的には, 前報 ${ }^{(5)}$ と 同様に起動時の軸振れ振幅の時刻歴，およびリサージュ波形の描画による軸心軌跡を測定し，これらを用いて軸 心収束時間，ならびに径方向軸振れ量などを算出する．特に本報では，軸受内周面の動圧効果発生に直接的に影 響を及ぼす軸受直径クリアランスをパラメータとして変化させ上記測定を実施することで，クリアランス変化に よる軸振れ特性への影響について具体的に報告していく，そしてこれらの実験結果より，モータの高速化，省工 ネルギー化につながる軸心収束時間の短縮，そして高精度・高信頼性化につながる軸振れ量の低減を達成する動 圧形状の仕様・組合せなどについて検討していく.

\section{2. スラスト・ラジアル動圧形状の仕様および組合せについて}

既報 ${ }^{(1) \sim(3)}$ の一連の定常状態における潤滑特性測定結果からの展開を試み，且つ非定常状態におけるクリアラ ンス変化による影響を検討する上で，スラストおよびラジアル動圧形状の組合せには前報 ${ }^{(5)}$ と同様のものを選定 する. 具体的にスラスト動圧形状には, PIN (Pump In), WAVE (Hydro Wave Bearing) の 2 形状を, ラジアル動 圧形状には，TLT（Three Lobed Type），HB（Herring Bone），および従来仕様として基準となる真円軸受 SLV（Sleeve Bearing）の 3 形状を採用している (図 1 に，それぞれの動圧形状概略図を示す)。なお，HB については前報 ${ }^{(5)}$ と同様, 平山らの報告 ${ }^{(6)}$ を参考に起動時軸振れ振幅の低減を目的とし, ランド溝幅比 $\boldsymbol{\alpha}(=\boldsymbol{b} \boldsymbol{g} / \boldsymbol{b} \boldsymbol{r}$, 図 1 (b) $\mathrm{HB}$ 参照）の違いにより HB I （ $\boldsymbol{\alpha}=0.5 ）$, HB II（ $\boldsymbol{\alpha}=0.3 ）$ の 2 種類を選定する. 動圧形状のテーパ深さあるいは溝深 さは，スラスト動圧形状が $15 \mu \mathrm{m}$ ，ラジアル動圧形状は $5 \mu \mathrm{m}$ であり，それぞれ浮上量あるいは半径クリアランス の 2 3 倍（溝深さ比 $\boldsymbol{\Gamma}=$ 溝深さ/半径クリアランス=2 3） と設定している. 摺動面となる気孔調整層の表面気孔率 $P s$ は, $P s=8 \sim 10 \%$ 程度に塑性流動を利用した機械加工プロセスにて調整・加工され, 動圧発生面全てにわたって $\boldsymbol{P} \boldsymbol{s}$ が統一して製作されている. 前報 ${ }^{(5)}$ と同様に, スラス卜動圧形状 PIN は, 流入角 $\boldsymbol{\beta}_{T}=18^{\circ}$ 程度, 溝本数は動圧 発生の非共振性を考慮し 7 本と決定した. これに対しWAVE の三次元的凹凸部は, 等分割に 3 箇所としている. ラジアル動圧形状 TLT についてはWAVE との対比を考慮した結果, くさび溝本数は 3 箇所とし, 図 1 (a) WAVE に示すように TLT の油溜り溝部をWAVE の凹部と一致させ動圧媒体である潤滑油の供給箇所を同一としている.

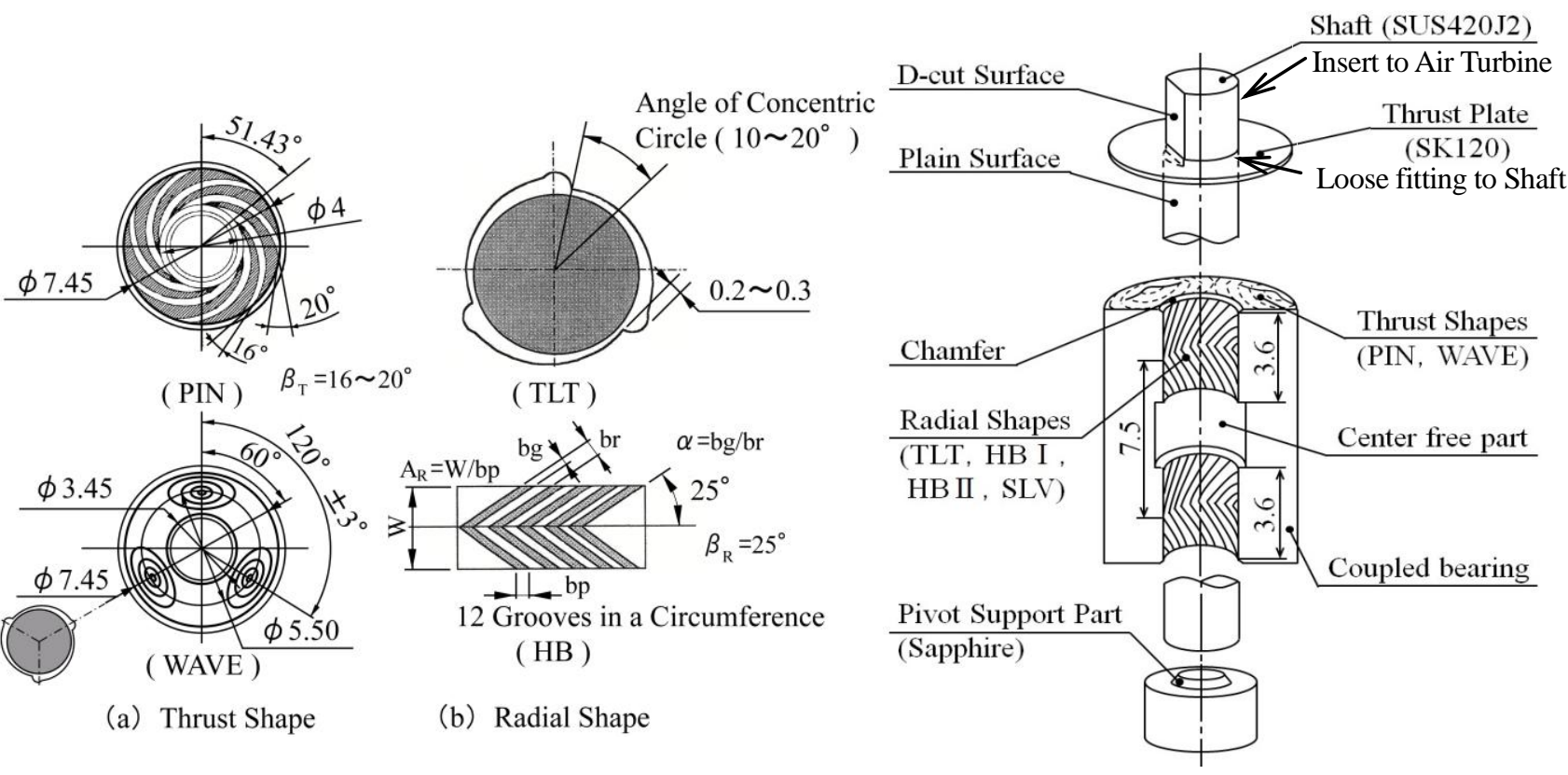

Fig.1 Thrust and radial shapes of coupled bearing

Fig.2 Construction of thrust-radial coupled bearing 
なお，その他の動圧形状の相対位置は特に規定せず金型上で任意の設定とした.さらにHB I , HB II については, 流入角 $\boldsymbol{\beta}_{\boldsymbol{R}}=25^{\circ}$ とし，アスペクト比 $\boldsymbol{A}_{\boldsymbol{R}}(=\boldsymbol{W} / \boldsymbol{b} \boldsymbol{p}=10$ 程度）を考慮した上で，溝本数はどちらも12本とした. 図 $2 に$ 複合軸受における動圧形状の組合せ，および組立て構造図を示す，スラスト動圧形状とラジアル動圧形状は，全 ての試料において図のように面取り部を挟んで相互に隣り合う位置関係に配置され（図の動圧形状例は端面： WAVE，内周面 : HB)，中逃げ部を除く2箇所（3.6mm×2）でラジアル荷重を支承できるよう製作してある.

上記のように，スラスト動圧形状2形状，そして基準となる真円形状SLVを加えたラジアル動圧形状4形状の組 合せからなる計 8 種類の複合軸受を製作した。 スラスト，およびラジアル動圧形状の仕様設計にあたっては，朱・ 小野(7), (8) らの解析による最適化や，十合(9), (10), Muijderman ${ }^{(11)}$ らの実験結果を参考とし，これを多孔質焼結体に 適用している. 図3にラジアル動圧形状として採用したTLT，HB I，HBII，ならびにSLVの溝形状などを含む径 方向形状寸法をそれぞれ表示している. 図に示寸ように, ラジアル動圧形状テーパ深さ，あるいは溝深さは5 $\mu \mathrm{m}$ 程度となっており，SLVの真円度は $1 \mu \mathrm{m}$ 以下であることが分かる. また， $V_{C=5 \sim 6}$ ならびに $V_{C=3-4}$ を図中に示すこと

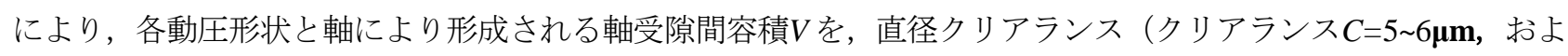
びC=3 4 $\mu \mathbf{m})$ ごとに明記した. 本記載により, このVが小さいほど起動時における早期の油膜形成がし易いとい う目安となる。 さらに, 図4には各種ラジアル動圧形状の動圧発生部におけるポーラス写真（図3破線枠部，軸受 中心方向より撮影）を掲載した．平滑円筒面をな寸軸は，写真の上部から下部に向かって油が流入する方向に回 転寸る. 図に示されるように各ラジアル動圧形状，および気孔の分布状態が良くうかがわれ，ばらつきはあるも のの全仕様ともほぼP $\boldsymbol{S}=10 \%$ 程度に気孔調整が施されている.

\section{3. 実 験 装 置}

図 5 に本実験で使用する軸受特性試験装置を示す. 図より, エアタービンは真ちゅう製の質量 $85 \mathrm{~g}$, 直径 $40 \mathrm{~mm}$ のものを使用する．エアタービン上部に装着するスラスト負荷重りの有無により，HDD 規格 $2.45 \mathbf{N}$ （250gf，ア ンバランス量 $0.3 \mathbf{g c m}$ )，DVD ドライブ規格 $0.833 \mathbf{N}$ （85gf，アンバランス量 $0.15 \mathbf{g c m}$ ）といった各スラスト負荷条 件での特性試験が可能な構成となっている.エアタービンの駆動は外周 4 方向からのエア吹付けにて行っており, 昇圧時（ $0 \rightarrow 0.4 \mathrm{MPa} ）$ のエア圧力は, 設定時間（20sec. $)$ に対して直線的に圧力が変化するよう電空レギュレー タ（ITV2030-012BS：SMC 製）にて調整されている，そして，レギュレータ開放後圧力は一定に保たれ，その設 定圧力, およびエア流量調整バルブにより軸回転数を 10000rpm 程度まで安定して調整することが可能である.

また，アクリル製の軸受ハウジングユニットは，内部に試料である複合軸受を挿入・固定する構造となってい る. さらに, 軸振れ振幅の時刻歴, および軸心軌跡測定のため, 複合軸受上部端面（スラス卜動圧形状形成面）

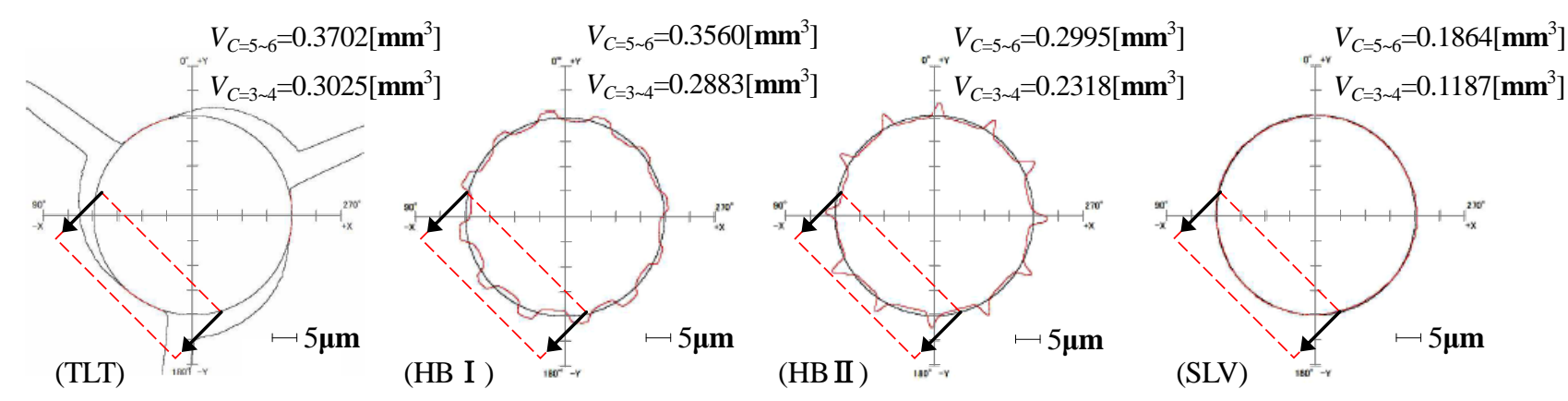

Fig.3 Radius dimension data of radial shapes
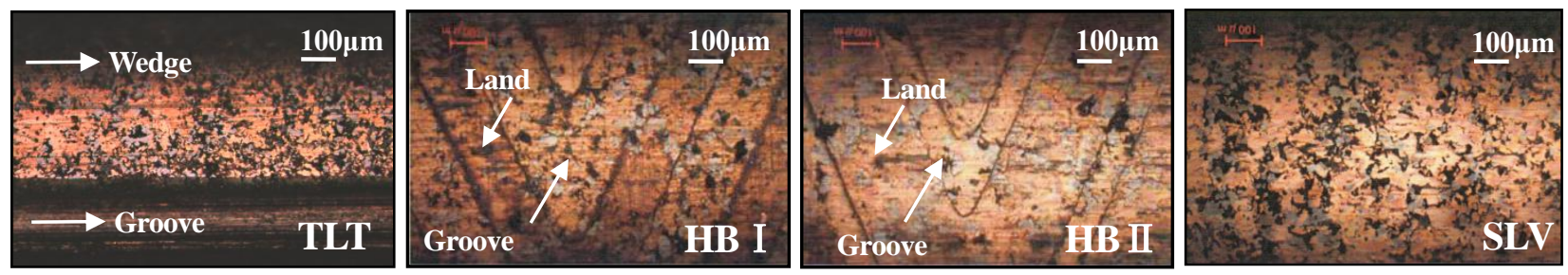

Fig.4 Porous photograph of radial shapes 
より $20 \mathrm{~mm}$ 下方位置，径方向 $X, Y$ の 2 方向に 2 つの渦電流変位センサ（VS-005L : 新川電機製）が設置してあ る．特性試験時には，軸受の内周面に対しエアタービンと共回りするステンレス鋼（SUS420J2）製の軸を，さら に端面に対しては Hi-Carbon 鋼（SK120）製のスラスト板をそれぞれ配置する．軸とスラスト板はDカット面に よりルーズフィットされ，スラスト板は常に動圧形状が形成された端面に倣い対向しながら共回りすることで, 端面動圧を発生する構成となっている (図 2 参照). なお, ラジアル動圧効果のみを検証する場合，ハウジングユ ニット内部下に図中破線で示すサファイヤ製のピボット受け部を挿入・固定し，同時にスラスト板を取り去る. これにより，軸下端をピボット支持し，スラスト動圧無付加状態にて実験を行う構成も可能である(5). 表 1 に実 験に使用した複合軸受，軸，およびスラスト板の寸法，組成，精度，ならびに潤滑油物性值を示す。

\section{4. 実 験 方 法}

\section{$4 \cdot 1$ 実験概要}

本研究では，複合軸受の非定常状態における軸心挙動の解明にあたって軸振れ振幅の時刻歴（以降，時刻歴）， および軸心軌跡について以下のような測定を行った。まず，ハウジングユニットの径方向 $X, Y, 2$ 方向に設置し た渦電流変位センサにより，軸起動から一定時間（50sec.）の時刻歴として，図 6 のような軸振れ振幅の波形が 高速マルチレコーダ（GR-7000 : KEYENCE 製）を用いて各方向にて測定される. このとき，2つの変位センサは 互いに直角方向に配置してあり，さらに軸心挙動の全容を知る目的で，双方からの出力をレコーダにより合成す る.これにより, 図 7 に示すリサージュ波形, すなわち軸心軌跡が描かれ，二次元的な軸心挙動の解明が可能と なる，そして，上記時刻歴より軸心収束時間，軸心軌跡より径方向軸振れ量の算出を行う。なお，レコーダの測 定条件としては，サンプリングレート：50 kS/sec., LPF : $5 \mathrm{kHz}$ と設定し測定を行っている.

\section{4-2 軸心収束時間および径方向軸振れ量の算出について}

上記実験にて得られた時刻歴，および軸心軌跡より，軸心収束時間（以降，収束時間），ならびに径方向軸振れ 量の算出を行う。まず，本研究において収束時間とは，軸起動後から時刻歴波形の振幅，すなわち軸振れ量が一 定となるまでに要する時間と規定する。この規定を全ての測定に適用する上で，軸受や含浸油の温度上昇による

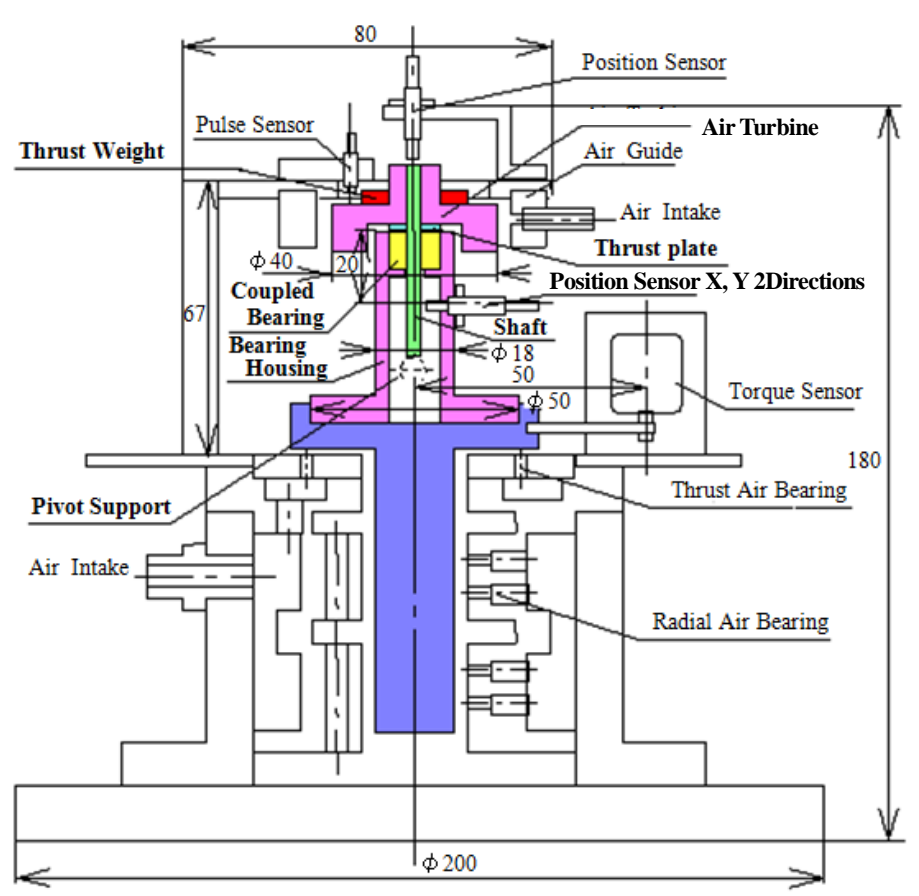

Fig.5 Device for measuring bearing characteristics

Table 1 Specimen dim.[mm], roughness, composition etc.

\begin{tabular}{|c|c|}
\hline $\begin{array}{l}\text { Bear. Dim. / } \\
\text { Composition }\end{array}$ & $\begin{array}{l}\phi 3 \times \phi 8 \times L 11.5 \quad(3.6 \times 2 \text { parts }), R_{Z}<1.0 \mathbf{S} \\
\text { Fe-Cu System, Permeability : } 8 \times 10^{-3} \boldsymbol{\mu m}^{2}\end{array}$ \\
\hline $\begin{array}{l}\text { Shaft Dim. } \\
\text { (SUS420J2) }\end{array}$ & $\begin{array}{l}d=2.994(C=5 \sim 6, C / d \doteqdot 0.2 \%) \times L 50 \\
d=2.996(C=3 \sim 4, C / d \fallingdotseq 0.1 \%) \times L 50 \\
R_{Z}<0.2 \mathrm{~S}, \text { Hardness }>650 \mathrm{Hv}, \text { Circularity }<0.4 \mu \mathrm{m}\end{array}$ \\
\hline $\begin{array}{l}\text { Thrust Plate } \\
\text { Dim. }\end{array}$ & $\begin{array}{l}\phi 3.1 \times \phi 7.60 \times t 0.5, \quad R_{Z}<0.15 \mathbf{S} \\
\text { Hardness }>650 \mathbf{H v}\end{array}$ \\
\hline $\begin{array}{l}\text { Oil } \\
\text { (VG68 rank) }\end{array}$ & 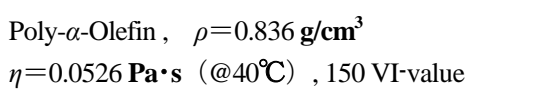 \\
\hline
\end{tabular}

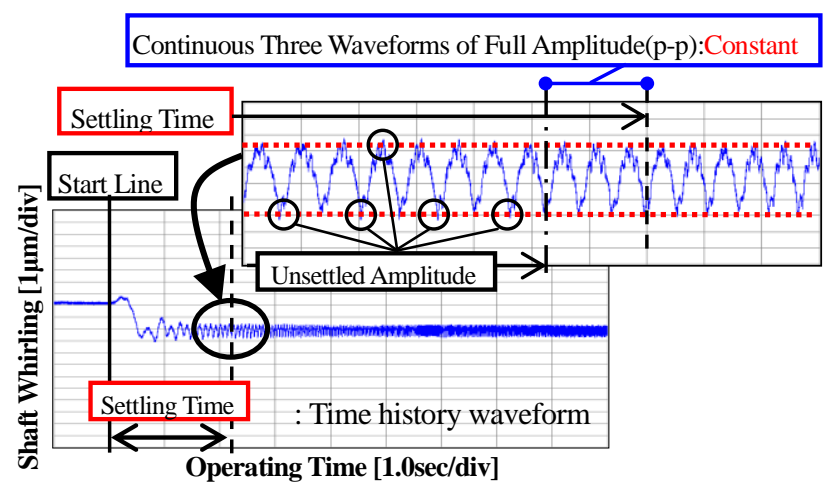

Fig.6 Principle for measuring the settling time by time history waveform 
時刻歴波形の時間的ドリフトなどの影響も懸念される，そのため，収束時間の測定にあたっては，図 6 より，軸 起動後から 3 波形連続で全振幅一定（入力電圧許容誤差：0.005\%以下）となった時，これを概括的に軸心の収束 とみなし，起動からそれまでの経過時間を計測するものとした．また，図７に示す軸心軌跡例において，横軸 $X$ と縦軸 $Y$ の軸振れ量 $x, y$ をそれぞれ測定し，両者の二乗和平方根 $\left(\phi_{w}=\sqrt{x^{2}+y^{2}}\right)$ を径方向軸振れ量 $\phi_{w}$ として算 出している. なお, 別途, 収束時軸振れ量を $\phi_{S T}$ と表記し, これについては, それぞれの動圧形状の収束時間にお ける軸心の径方向軸振れ量として算出した.

\section{$4 \cdot 3$ 実験条件}

本実験は以下の表 2 に示寸実験条件にて行った，なお，非定常状態についての検討を行うため，回転数勾配： $d N / d T$ を, 前報 ${ }^{(5)}$ と同様に軸起動から $20 \mathrm{sec}$.で 5000rpm へほぼ直線的に到達するよう $d N / d T=250(\mathbf{r p m} / \mathbf{s e c}$. : 実機 時間軸を約 50 倍に拡大） と規定し, 電空レギュレータにてエア圧力調整を行っている. また, 摺動面摩擦係数 や含浸油温度の平衡を考慮し実験初期に際しては, あらかじめ60min.の複合軸受としてのなじみ運転を行う。さ らに，測定開始前には $60 \mathrm{sec}$.のならし運転を行い，その後実際の測定を開始する．それぞれの組合せにおける測 定回数は $n=5$ 回とし，その算術平均を定量的代表値とした。 なお，各測定に対する測定間隔は表 2 に示すように $60 \mathrm{sec}$ としている. 本報では，軸受直径クリアランス（以降，クリアランスまたは $C$ と表記）を実験パラメータ として用い, クリアランス変化が軸振れ挙動一与える影響を明らかにする. 前報(5)の実験においては, Morgan ${ }^{(12)}$ の研究報告に基づき, クリアランスと軸直径との比 : $C / d$ が推奨值である $0.2 \%$ 程度となるように, $C=5 \sim 6 \mu \mathrm{m}$ (前 報 ${ }^{(5)}$ では半径クリアランス 2 3 $\boldsymbol{\mu m}$ と表記，以降これを $C=5 \sim 6$ と記述する）としてきた. クリアランスはラジア ル方向発生動圧，ひいては負荷容量や油膜剛性に大きく寄与する因子であり，著者らは新たに $C / d$ が約 $0.1 \%$ と なる $C=3 \sim 4 \mu \mathrm{m}$ (以降, $C=3 \sim 4$ と記述）を採用し， 2 通りのクリアランス条件にて同様の実験を行った. なお，ク リアランスの調整に際しては, 調整の容易さ, 加工精度, コストなどを勘案し, 表 1 に示すように回転軸直径の 異なる 2 種類の軸を用いてクリアランス調整を実施している.

以上の実験条件をふまえ，それぞれ，(1)軸下端ピボット支持（スラスト動圧無付加状態）タイプ，および(2)複

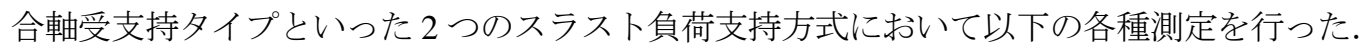

(1) 軸起動から 50sec.間における時刻歴の測定

(2) 上記時刻歷による収束時間，および収束時軸振れ量 $\phi_{S T}$ の算出

（3）各回転数（1000 6000 rpm，1000 rpm ごと）時における軸心軌跡の測定

（4）上記軸心軌跡による（二乗和平方根）径方向軸振れ量 $\phi_{w}$ の算出

\section{5. 実 験 結 果}

\section{$5 \cdot 1$ 収束時間および収束時軸振れ量 $\phi_{S T}$ 算出結果について（ピボット支持タイプ）}

以下に本実験で得られた測定結果を示寸。なお，特に断らない限りスラスト負荷条件は，HDD 規格（2.45N, アンバランス量 $0.3 \mathrm{gcm}$ ）とし, さらに今後各種動圧形状の仕様をハイフンでつないで示寸場合, 前者をスラスト 動圧形状, 後者をラジアル動圧形状として複合軸受を表すものとする. また, $C=5 \sim 6$ の実験結果に関しては, 前 報 (5) との重複を避けるため要点だけを簡単に述べるものとし, 詳細については前報を参照して頂きたい.

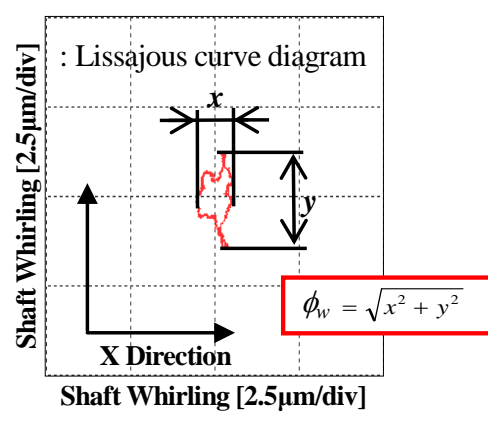

Fig.7 Principle for measuring the shaft whirling $\phi_{w}$ by lissajous curve diagram
Table 2 Test Condition

\begin{tabular}{l|l}
\hline Thrust Load / Dynamic Imbalance & $2.45 \mathbf{N}(250 \mathbf{g f}) \quad / 0.3 \mathbf{g c m}(@ 2.45 \mathbf{N})$ \\
\hline Hydrodynamic Shapes & $\begin{array}{l}\text { Thrust Hydrodynamic Shapes : WAVE, PIN } \\
\text { Radial Hydrodynamic Shapes : HB I, HB II, TLT, SLV }\end{array}$ \\
\hline Revolution Speed & $0 \mathbf{r p m} \sim 7000 \mathbf{r p m}$ \\
\hline Environmental Temperature & $20 \pm 2^{\circ} \mathrm{C}$ \\
\hline Diametral Clearance : $C$ & $5 \sim 6 \mu \mathbf{m}(C / d \doteqdot 0.2 \%), 3 \sim 4 \mu \mathrm{m}(C / d \doteqdot 0.1 \%)$ \\
\hline Measuring Time Interval & 60 sec. \\
\hline
\end{tabular}


表 3，および 4 に，(1)軸下端ピボット支持タイプ（以降，ピボット支持）における各軸受仕様の収束時間，お よび収束時軸振れ量 $\phi_{S T}$ の一覧表を $C=5 \sim 6, C=3 \sim 4$ の順に示す.さらに図 8 に各クリアランス, 各軸受仕様でのピ ボット支持における $X$ 方向の時刻歴を代表值として示しており, 図中の上が $C=5 \sim 6$, 下が $C=3 \sim 4$ における時刻歴 の配置となっている．また，表 5，および 6 に，5.2 項で述べる上記と同様のクリアランスごとの(2)複合軸受支持 タイプ (以降，複合支持）における各軸受仕様の収束時間，および収束時軸振れ量 $\phi_{S T}$ の一覧表を示し，さらに図 8 と同様に，複合支持における各クリアランス，各軸受仕様の $X$ 方向時刻歴を図 9 に示す. なお，それぞれの表 中にある収束時間 $\left(N_{R}\right)$ の番号 $N_{R}$ を用いて, ラジアル動圧形状を主パラメータ，またスラスト動圧形状を副パ ラメータとした場合の各種動圧形状組合せにおける優劣順位を優れた順に表している.

まず，ピボット支持における測定結果，ならびにクリアランス変化の影響について述べる．各ラジアル動圧形 状の収束時間を比較すると, 表 3 より C=5 6 において収束が早い順に HB I < HB II < TLT 《SLV という順位付け となった. このとき，ラジアル動圧形状仕様（HB I ，HB II，TLT）の間には最も早い HB I の 5.10sec.を最高值 とし，それぞれ 1.0〜 1.5sec.程度，さらに TLT と SLV の間には 3.0sec.程度の収束時間の差がみられる.また収束 時軸振れ量 $\phi_{S T}$ については, 表 3 に示すように全形状において 3.0 4.0 $\mu \mathrm{m}$ 程度とあまり大差はなく, 概して収束時 間が長くかかるほど $\phi_{S T}$ が小さくなる傾向であった.

また, 表 4 より $C=3 \sim 4$ における各ラジアル動圧形状の収束時間比較を行ったところ，早い順に HB I $\fallingdotseq \mathrm{HB}$ II $<$ TLT $\ll S L V$ という順位付けとなり，最も早いHB I の 3.97sec.を最高值とし，順位差のある各ラジアル動圧形状間 での収束時間の差は $C=5 \sim 6$ における場合と同程度であった。また， $C=3 \sim 4$ における収束時軸振れ量 $\phi_{S T}$ にいて は，表 4 に示すようにラジアル動圧形状仕様はほぼ $1.5 \mu \mathrm{m}$ 程度と $C=5 \sim 6$ に比較し半減するのに対し，SLVでは $2.6 \mu \mathrm{m}$ 程度と僅かな改善しか夕られない結果となっている.さらに，図 8 より $C=5 \sim 6$ ，および $C=3 \sim 4$ における時 刻歴に着目すると，どちらのクリアランスでも動圧発生により起動当初から全測定域にわたり軸振れ全振幅がほ ぼ安定するラジアル動圧形状仕様に対し，動圧発生に乏しいSLV は一時的に軸振れ振幅の収束をみせるものの， その後全振幅は逓増傾向を示し不安定な状態を呈している.

ここで，ピボット支持における測定結果として $C=5 \sim 6$ と $C=3 \sim 4$ の比較を行うと, クリアランスの減少により， ラジアル動圧形状仕様において 1.1 2.4 sec.程度, SLV においては約 1.8 sec.程度の収束時間の短縮がみられた. こ れは何れの仕様でも $C / d$ を $0.2 \%$ から $0.1 \%$ 程度と狭めたことにより, 軸起動当初より軸一軸受間における早期の 油膜形成が可能となることで動圧が発生し，また油膜剛性も向上することから軸受内周面動圧に起因する復元モ 一メント（ラジアル負荷容量増分×軸受スパン長さ：7.5mm）が高まり軸心収束時間の短縮が促された結果であ る. また, 特に収束時軸振れ量 $\phi_{S T}$ の改善は目覚ましく, クリアランスの減少によりラジアル動圧形状仕様では

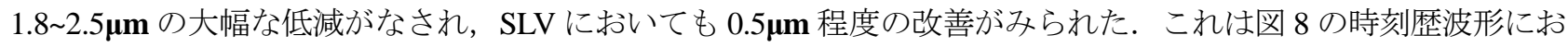
けるクリアランス比較からも明らかであり, ラジアル動圧形状仕様では軸起動直後から早期の油膜形成がなされ,

Table 3 Settling time and shaft whirling $\phi_{S T}$ on settling time (at pivot support, @C=5 6)

\begin{tabular}{l|c|c|c|c}
\hline & HB I & HB II & TLT & SLV \\
\hline \hline Settling Time [sec.] & $5.10(1)$ & $6.62(2)$ & $7.85(3)$ & $10.64(4)$ \\
\hline Shaft Whirling $\phi_{S T}$ on & 3.92 & 3.73 & 3.46 & 3.06 \\
Settling Time $[\boldsymbol{\mu m}]$ & $\{4.5\}$ & $\{3.5\}$ & $\{8.0\}$ & $\{8.0\}$ \\
\hline
\end{tabular}

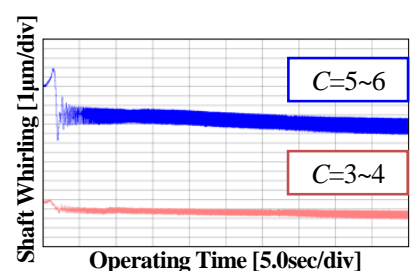

(a) HB I

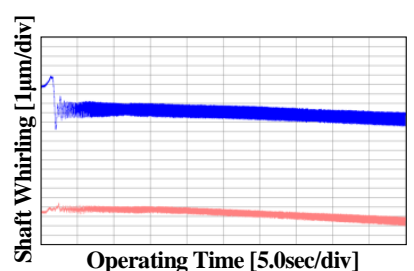

(b) HB II

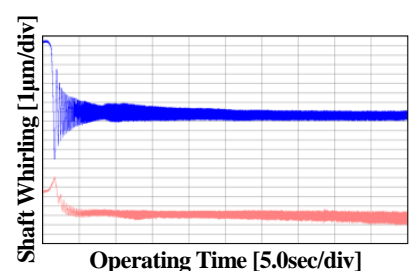

(c) TLT

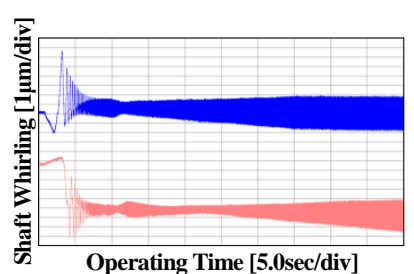

(d) SLV

Fig.8 Time history waveform at each clearance on $X$-axis (at pivot support, $0 \sim 50$ sec.) 
クリアランスの減少により油膜剛性が向上することから，軸受内周面動圧に起因する復元モーメントも高まり軸 振れ抑制効果として働くことで回転数全域にわたる全振幅の減少がうかがえる. 同様に SLVについても，ラジア ル動圧形状仕様に比べれば僅かではあるが，図 8 (d) より上記収束時軸振れ量 $\phi_{S T}$ の改善状況が回転数全域にわ たって全振幅が抑制されていることから見てとれる。しかしながら，SLVではクリアランス減少に伴い全振幅は 幾分抑制されるものの，その経時変化は未だ安定化されているとは言い難い状況にある．なお，各ラジアル動圧

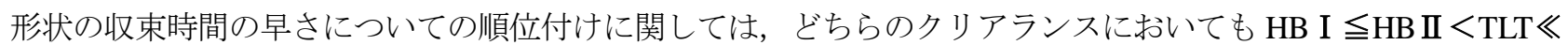
SLV といった結果となり，小野 ${ }^{(8)} ら の$ 解析結果より動圧形状の動特性，軸受剛性はほぼ同等であるが，特にダン パ係数において TLTよりも HB の方が優れていることから上記の様な順位付けになったものと判断される.

一方，図 8 より軸起動直後の軸振れ最大振幅（表 $3 ， 4$ の $\phi_{S T}$ 枠下段 \{\}内に，図 8 から読み取った大まかな実

Table 5 Settling time and shaft whirling $\phi_{S T}$ on settling time (at coupled bearing, @ C=5 6)

\begin{tabular}{|c|c|c|c|c|c|c|c|c|}
\hline & \multicolumn{2}{|c|}{ HB I } & \multicolumn{2}{|c|}{ HB II } & \multicolumn{2}{|c|}{ TLT } & \multicolumn{2}{|c|}{ SLV } \\
\hline & WAVE & PIN & WAVE & PIN & WAVE & PIN & WAVE & PIN \\
\hline Settling Time [sec.] & $2.60(1)$ & $2.88(1)$ & $3.03(2)$ & $3.59(2)$ & $4.27(3)$ & $4.71(3)$ & $6.20(4)$ & $8.06(4)$ \\
\hline $\begin{array}{l}\text { Deviation from } \\
\text { WAVE [sec.] }\end{array}$ & - & +0.28 & - & +0.56 & - & +0.44 & - & +1.86 \\
\hline $\begin{array}{l}\text { Shaft Whirling } \phi_{S T} \text { on } \\
\text { Settling Time }[\boldsymbol{\mu} \mathbf{m}]\end{array}$ & $\begin{array}{l}2.34 \\
\{3.0\}\end{array}$ & $\begin{array}{l}2.93 \\
\{2.0\}\end{array}$ & $\begin{array}{l}3.11 \\
\{2.0\}\end{array}$ & $\begin{array}{l}3.06 \\
\{1.5\}\end{array}$ & $\begin{array}{c}2.81 \\
\{5.5\}\end{array}$ & $\begin{array}{l}2.87 \\
\{5.0\}\end{array}$ & $\begin{array}{l}3.42 \\
\{8.5\}\end{array}$ & $\begin{array}{l}3.30 \\
\{6.5\}\end{array}$ \\
\hline $\begin{array}{l}\text { Deviation from } \\
\text { WAVE }[\boldsymbol{\mu m}]\end{array}$ & - & +0.59 & - & -0.05 & - & +0.06 & - & -0.12 \\
\hline
\end{tabular}

Table 6 Settling time and shaft whirling $\phi_{S T}$ on settling time (at coupled bearing, @ $C=3 \sim 4$ )

\begin{tabular}{|c|c|c|c|c|c|c|c|c|}
\hline & \multicolumn{2}{|c|}{ HB I } & \multicolumn{2}{|c|}{ HB II } & \multicolumn{2}{|c|}{ TLT } & \multicolumn{2}{|c|}{ SLV } \\
\hline & WAVE & PIN & WAVE & PIN & WAVE & PIN & WAVE & PIN \\
\hline Settling Time [sec.] & $1.96(1)$ & $2.21(1)$ & $2.70(2)$ & $2.96(2)$ & $3.47(3)$ & $3.93(3)$ & $4.28(4)$ & $5.64(4)$ \\
\hline $\begin{array}{l}\text { Deviation from } \\
\text { WAVE [sec.] }\end{array}$ & - & +0.25 & - & +0.26 & - & +0.46 & - & +1.36 \\
\hline $\begin{array}{l}\text { Shaft Whirling } \phi_{S T} \text { on } \\
\text { Settling Time }[\mu \mathbf{m}]\end{array}$ & $\begin{array}{l}1.09 \\
\{1.5\}\end{array}$ & $\begin{array}{l}1.21 \\
\{1.0\}\end{array}$ & $\begin{array}{l}1.10 \\
\{1.5\}\end{array}$ & $\begin{array}{l}1.22 \\
\{1.0\}\end{array}$ & $\begin{array}{l}1.28 \\
\{1.5\}\end{array}$ & $\begin{array}{l}1.19 \\
\{1.5\}\end{array}$ & $\begin{array}{l}2.42 \\
\{5.0\}\end{array}$ & $\begin{array}{l}2.87 \\
\{4.5\}\end{array}$ \\
\hline $\begin{array}{l}\text { Deviation from } \\
\text { WAVE }[\boldsymbol{\mu m}]\end{array}$ & - & +0.12 & - & +0.12 & - & -0.09 & - & +0.45 \\
\hline
\end{tabular}

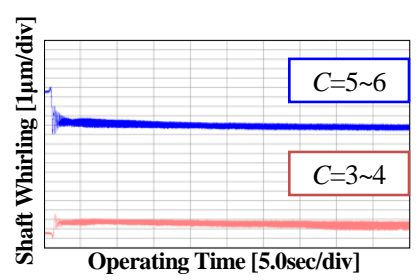

(a) WAVE-HB I

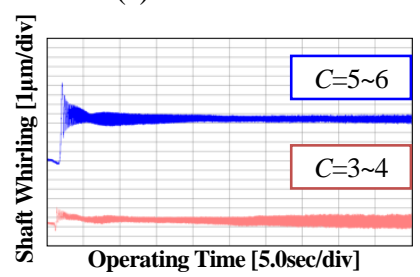

(e) WAVE-TLT

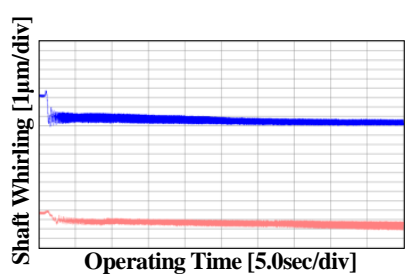

(b) PIN-HB I

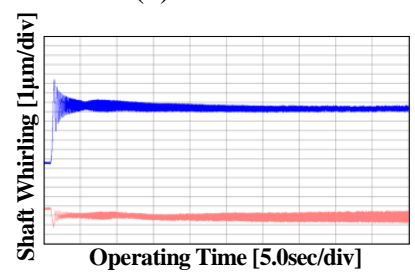

(f) PIN-TLT

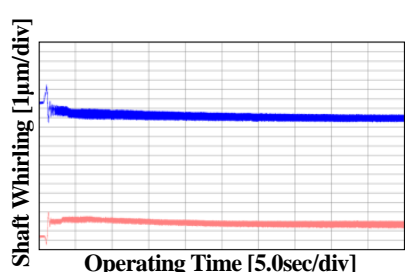

(c) WAVE-HB II

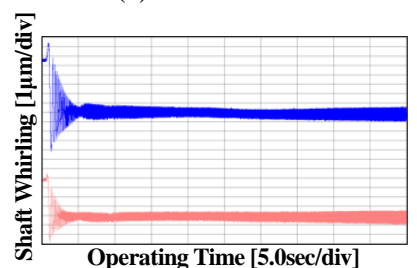

(g) WAVE-SLV

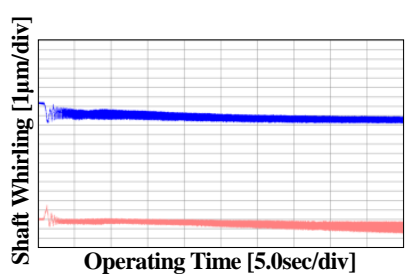

(d) PIN-HB II

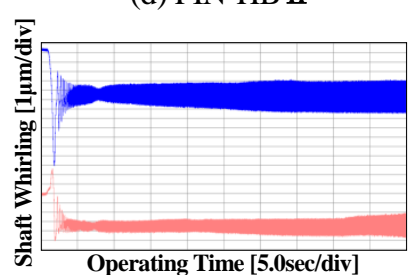

(h) PIN-SLV

Fig.9 Time history waveform at each clearance on $X$-axis (at coupled bearing, $0 \sim 50$ sec.) 
力值を示す）の優劣を少ない順に順位付けると，双方のクリアランスにて HB II $\leqq \mathrm{HB} \mathrm{I}<\mathrm{TLT} \leqq \mathrm{SLV}$ となり，決 定的な差とは言えないまでも平山らの報告 ${ }^{(6)}$, 寸なわち「HB I $(\boldsymbol{\alpha}=0.5)$ に比較し HB II $(\boldsymbol{a}=0.3)$ の方が起動時 軸振れ振幅を低減可能」を裏付ける結果となった。この理由としては, 起動時の非定常状態において比較的早い 段階で溝部が潤滑油で満たされる HB II（ $\boldsymbol{\alpha}$ の違いにより溝部容積が HB I に比較し少ないため : 図 3 の各軸受隙 間容積 $V$ の值を参照のこと)の方が, 早期の油膜形成による負荷容量や油膜剛性を確保し易いためと推察される. さらに, ラジアル動圧形状仕様においては, クリアランスの減少に伴い軸起動直後の軸振れ最大振幅は, $C=5 \sim 6$ における測定結果の約 1/3 1/4 の全振幅へと大幅な低減がみられた. しかしながら, SLVにおいては軸起動直後 の軸振れ最大振幅にそれほど大きな変化はなく, 単にクリアランス減少分の良化傾向がうかがえる程度で円すい モード系にて振れ回る様相を呈している.これらの測定結果から, ラジアル動圧形状仕様においては $C / d$ を $0.1 \%$ 程度とすることで軸起動当初からの早期の油膜形成とそれに伴う動圧発生，および油膜剛性が向上することから 軸受内周面動圧に起因する復元モーメントも高まり, 軸心の早期収束, および対軸振れ抑制効果が充分に促進さ れるものと判断される.

\section{$5 \cdot 2$ 収束時間および収束時軸振れ量 $\phi_{S T}$ 算出結果について（複合支持タイプ）}

次に，複合支持における測定結果，およびクリアランス変化の影響について言及する．まず，表 5 より $C=5 \sim 6$ における複合支持の収束時間測定結果をみると，スラス卜動圧形状を付与寸ることで，同じクリアランスでのピ ボット支持に比べ全仕様とも収束時間が約 1/2 2/3（実測值で 2.5 4.5 sec.の低減）へと大幅に短縮され, 収束時 間の早い順位付けは，最も早い WAVE-HB I の 2.60sec.を最高值とし，ピボット支持における場合と全く同様の結 果（HB I < HB II <TLT 《SLV）となった．また，収束時軸振れ量 $\phi_{S T}$ に関しては複合支持化により SLV 仕様を除 く 3 つのラジアル動圧形状仕様では, ほぼ $2.8 \mu \mathrm{m}$ 程度と全体として $0.6 \sim 1.6 \mu \mathrm{m}$ の良化がみられるのに対し, SLV 仕様に関しては $3.4 \mu \mathrm{m}$ 程度と，逆に若干ではあるが約 $0.3 \mu \mathrm{m}$ の悪化傾向を呈する結果となった.

また, 表 6 より, $C=3 \sim 4$ における複合支持での各ラジアル動圧形状に対する収束時間の比較を行ったところ, $C=5 \sim 6$ の複合支持と同様に，同じクリアランスでのピボット支持に比べ全仕様とも収束時間が約 1/2 2/3（実測 值で 1.5 4.5 sec.の低減) へと大幅に短縮され，収束時間の早い順位付けも最も早い WAVE-HB I の 1.96sec.を最高 值とし同様の結果となった. 一方, 収束時軸振れ量 $\phi_{S T}$ に関する比較を行うと, 複合支持化により SLV 仕様を除 く 3 つのラジアル動圧形状仕様では，約 $1.2 \mu \mathrm{m}$ とピボット支持に比べ全体として $0.1 \sim 0.5 \mu \mathrm{m}$ の良化に留まり， SLV 仕様では $2.6 \mu \mathrm{m}$ 程度とほぼ変化のない状況であった. なお，図 9 に示寸時刻歴をピボット支持の場合と比較 すると, PIN-SLV を除く全仕様にて軸振れ振幅が全体的に減少し，さらに安定して推移していることが分かる.

ここで, 複合支持における測定結果として $C=5 \sim 6$ と $C=3 \sim 4$ の比較を行うと, クリアランス減少による収束時 間の短縮効果としては，ラジアル動圧形状仕様において約 0.4 0.8 sec.程度，SLV 仕様においては約 2.0 2.4 sec.程 度となった. 加えて, 同様にクリアランス減少による収束時軸振れ量 $\phi_{S T}$ の抑制効果は, ラジアル動圧形状仕様

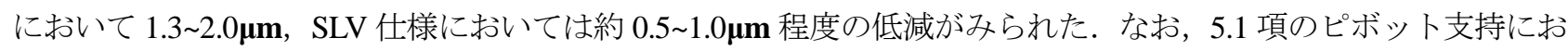
けるクリアランス減少による効果との比較を行ってみると, 総じて収束時間の短縮効果に関しては複合支持化の 方の寄与率が 2 倍程度大きく影響し, 逆に収束時軸振れ量 $\phi_{S T}$ の低減に関しては複合支持化よりも $C / d$ を $0.1 \%$ 程度へとクリアランスを減少させる方が寄与率として2 3 倍程度大きく，より効果的であることが判明した.

さらに, 図 9 の複合支持における時刻歴のクリアランス比較より, $C=3 \sim 4$ の全ての仕様において軸起動直後か ら 30sec.程度までの時間経過では，軸振れ振幅が最大振幅值を含めても $C=5 \sim 6$ の值の 1/2 1/3 程度まで低減して いることがみてとれる.しかしながら，30sec.経過した辺りから軸振れ振幅は微増傾向にあり，50sec.に達した時 には $C=5 \sim 6$ の值とほぼ同等か, あるいは僅かながら悪化する傾向もうかがえる.これは, クリアランスの減少と 複合支持化により，潤滑油が過度のせん断応力を受けることで油温が上昇し，油の粘度低下により負荷容量や油 膜剛性が減じられたために生じた現象であると推察される.この現象は, 図 8 に示寸ピボット支持におけるクリ アランス減少時にもその傾向が僅かながら見られることから，寸法公差を含むクリアランスの適正化とスラスト 負荷支持タイプの選定をする上で，軸受システムとしての設計方針や，概して高精度化あるいは長寿命化といっ た望目特性を達成するためのアプローチの仕方に関し多くの示唆を与える実験結果であると言える.

一方，複合支持における軸起動直後の軸振れ最大振幅（表 5, 6 の $\phi_{S T}$ 枠下段 \{\} 内に図 9 から読み取った大ま かな実力值を示す）の優劣を少ない順に順位付けると，双方のクリアランスにてピボット支持の場合とほぼ同様 
に HB II $\leqq \mathrm{HB} \mathrm{I}$ < TLT< SLV となった. さらに，C=5 6におけるラジアル動圧形状仕様では複合支持とすること で，ピボット支持の最大振幅の約 $1 / 2$ にまで軸振れが低減されている．これに対し SLV 仕様は，複合支持として も最大振幅にあまり大きな変化はなく, ピボット支持と同等あるいは若干悪化傾向を示し，軸起動直後において は約 $10 \mu \mathrm{m}$ の最大振幅（C=5 6における円すいモード系振れ回りの幾何学的最大軸振れ量を意味する.ちなみに $C=3 \sim 4$ ではこの最大軸振れ量は約 $6 \mu \mathrm{m}$ となる）にて円すいモード系で振れ回る様相を呈している．なお，複合支 持における起動直後の最大振幅に対するクリアランスの減少効果は，先に上記複合支持化による最大振幅の低減 作用が功を奏しているため, 総じてピボット支持の場合ほじ顕著ではない. しかしながら，TLT 仕様のみは，こ の複合支持におけるクリアランス減少効果が特に顕著であり，上記複合支持化による半減に加え，最大振幅をさ らに 1/3 以下に低減させる結果となっている.これは，他のラジアル動圧形状に比較し，TLT 仕様は 3 箇所のテ

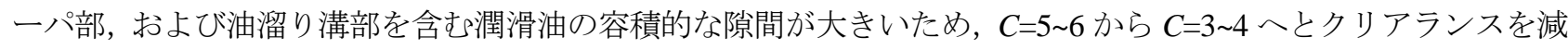
少させた場合，隙間容積の縮小や静止時の初期軸心ずれ量が減少することで径方向油膜形成のし易さに大きく影 響し, 軸起動直後の最大振幅抑制により効果的に作用するためと推察される（図 3 の各軸受隙間容積 $V$ の值を参 照のこと，なお，TLTの油溜り溝部の隙間容積 $V^{\prime}$ は $V$ ’3 $3.2644\left[\mathbf{m m}^{3}\right]$ と他の動圧形状に比べ桁違いに大きい).

ここで，2つのスラスト動圧形状による収束時間の変化に着目すると，表 5, 表 6, および図 9 の測定結果から 全ての仕様において PIN に比べWAVEの方の収束時間が短縮されていることが分かる. さらに SLV 仕様におい ては, WAVEとの複合化により早期に収束し, かつその後全体としての軸振れ量も少なく安定して推移している. この要因としては, 前報 ${ }^{(5)} に て$ 述べた端面最大圧力発生位置の違いによる WAVE の軸振れに対する復元モーメン トの優位性，ならびに端面径方向動圧発生による求心力や端面凸部摩擦力といった WAVE の形状的特徵に起因す るものであると推察される（図 1 スラスト動圧形状参照のこと）。つまり，起動時に発生する円すいモード系の軸 振れを抑制する場合, PIN に比べその復元モーメント（スラスト負荷容量増分 $\times$ 端面最大圧力発生半径）の大き さで端面最大圧力発生位置の寸法が 1.4 倍程度（WAVE： $\phi 5.5 / \mathrm{PIN}: \phi 4.0 \fallingdotseq 1.4$ ) と比較的大きな WAVE の方が, SLV を含む全ての仕様において収束時間の短縮や軸振れ抑制効果で有利に働くものと考えられる。この端面動圧 に起因する復元モーメントが，回転軸の角度変化や径方向変位といった軸心振れ回り挙動の抑制につながり，軸 心の早期収束や軸振れ量の安定化といった点で, PIN に比べWAVEの方が優れる結果に結びついたものと判断さ れる. なお，WAVE はスラスト動圧形状として時計回り，反時計回りの両回転方向にも使用可能であり，両回転 仕様でも同様な効果を期待できるといった利点も備えている.

以上のことから高速化, 省エネルギー化につながる最も早期の軸心収束を可能とする動圧形状組合せは, $C=3 \sim 4$ における WAVE-HB I 仕様であると判断される。なお，軸振れの高精度化といった観点においては，まずはクリ アランスの狙いを軸径の $0.1 \%$ 程度に設定し効果的にラジアル動圧の早期発生を促し, 次に複合支持化による双 方向動圧の相乗効果を寄与させることで, 軸起動当初からのさらなる低軸振れ化が可能になると言える.

\section{5・3 リサージュ波形測定結果について}

図 10 13 は， $X, Y$ 双方の時刻歴より任意の回転数における軸心軌跡を抽出し，その代表值として 6000rpm 時 のピボット支持，および複合支持での $C=5 \sim 6$ ，ならびに $C=3 \sim 4$ におけるリサージュ波形を示したものである. な お，ページ数の都合上，また上記収束時軸振れ量 $\phi_{S T}$ の差がラジアル動圧形状仕様間ではあまり顕著でないこと も鑑み, ラジアル動圧形状については動圧形状仕様を代表して HB I を, さらにその比較対象として真円形状 SLV のみを掲載することとした $\left(C=5 \sim 6\right.$ における, 他の動圧形状仕様のリサージュ波形詳細は前報 ${ }^{(5)}$ 参照されたい).

図 10 より，C=5 6, ピボット支持におけるラジアル動圧形状仕様 HB I のリサージュ波形は，非定常状態にお いても, 若干振れが大きい縦軸 $Y$ 方向で $2 \mu \mathrm{m}$ 程度と軸心軌跡の軸振れが抑制されている. それに対して SLV は, 横軸 $X$, 縦軸 $Y, 2$ 方向とも $3 \sim 5 \mu \mathrm{m}$ 程度の軸振れが見受けられ，6000rpm 時に軸が円すいモード系にて振れ回り 状態を呈していることが判明した.

また，図 11 より同ピボット支持にてクリアランスを $C=3 \sim 4$ と減少させることで，ラジアル動圧形状仕様であ る HB I においては軸心軌跡の軸振れが大幅に低減することが明らかであり，その実測值は $X, Y$ 双方向共に $1 \mu \mathrm{m}$ 程度にまで減少している，さらに，SLVにおいても同様なクリアランス減少により，上記の円すいモード系振れ 回り挙動が軽減されており， $X$ 方向， $Y$ 方向の軸振れがどちらも $2 \sim 3 \mu \mathrm{m}$ 程度に抑制されている. これらのリサ ージュ波形測定結果からも，前項で述べたクリアランス減少による対軸振れ抑制効果の顕著さが裏付けられる. 


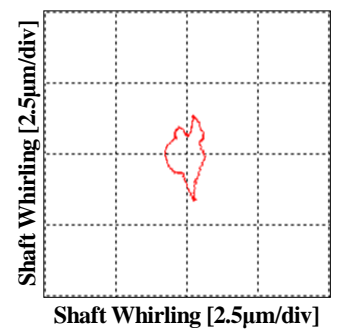

(a) HB I

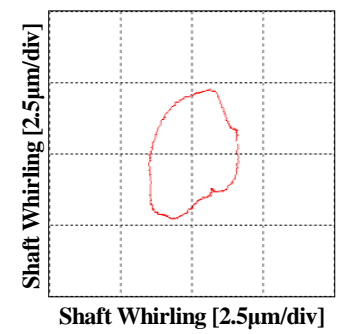

(b) SLV

Fig.10 Lissajous curve diagrams on HB I \& SLV (at pivot support, 6000rpm, @C=5 6) ${ }^{(5)}$

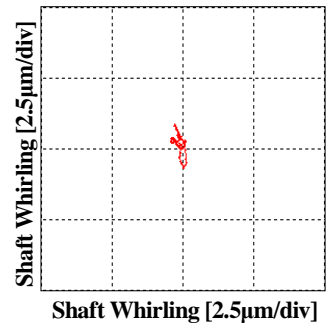

(a) WAVE-HB I

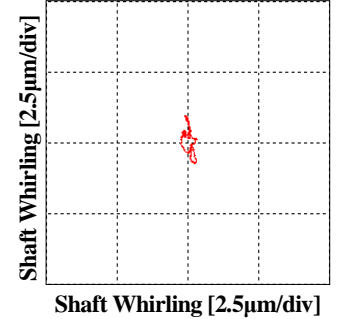

(b) PIN-HB I

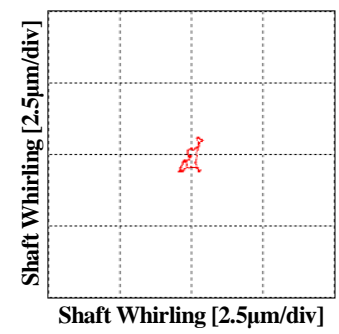

(a) HB I

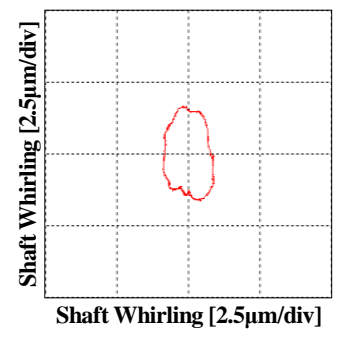

(b) SLV

Fig.11 Lissajous curve diagrams on HB I \& SLV (at pivot support, 6000rpm, @ $C=3 \sim 4$ )

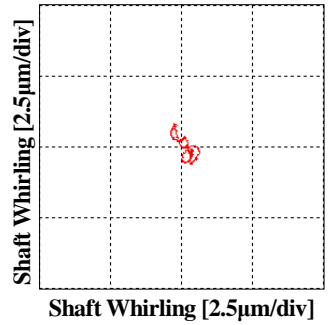

(c) WAVE-SLV

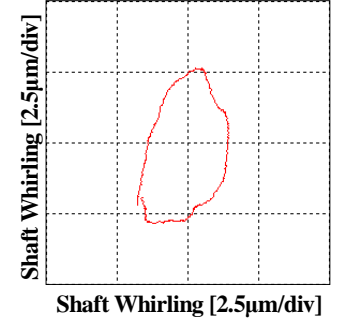

(d) PIN-SLV

Fig.12 Lissajous curve diagrams on (WAVE or PIN) - HB I \& SLV (at coupled bearing, 6000rpm, @C=5 6) ${ }^{(5)}$

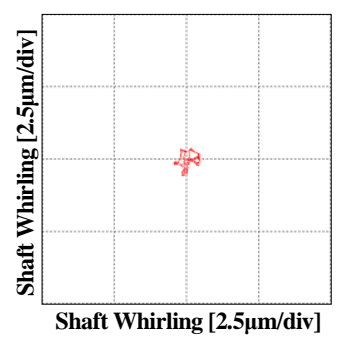

(a) WAVE-HB I

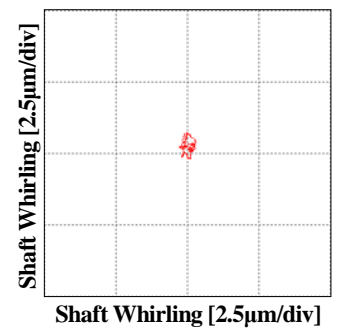

(b) PIN-HB I

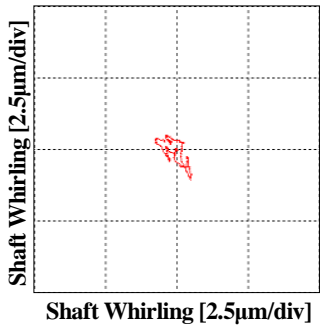

(c) WAVE-SLV

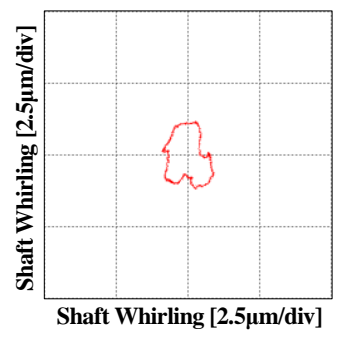

(d) PIN-SLV

Fig.13 Lissajous curve diagrams on (WAVE or PIN) - HB I \& SLV (at coupled bearing, 6000rpm, @ C=3 4)

次に，図 12 の $C=5 \sim 6$ にて複合支持におけるリサージュ波形測定結果をみると，図 10 の $C=5 \sim 6$, ピボット支持 6000rpm 時に比べ, WAVE, PIN どちらのスラスト動圧形状組合せでも HB I 仕様では軸心軌跡の軸振れが 1/2 1/3 である $1 \mu \mathrm{m}$ 程度に低減されている。これに対し，内周面に動圧形状を持たない SLV 仕様においては，PIN との 組合せではスラスト動圧形状の効果が全く発揮されないものの，WAVE と複合支持化することで軸心軌跡の軸振 れは $1 / 3$ 以下である $1 \boldsymbol{\mu m}$ 程度にまで低減し，HB I 仕様とほぼ同程度の軸心振れを呈す結果となった。

さらに，図 13 より複合支持にて $C=3 \sim 4$ とクリアランスを減少させることで, WAVE, PIN どちらのスラスト動 圧形状においても HB I 仕様では軸心軌跡の軸振れが特に縦軸 $Y$ 方向の振れ量の低減を顕著に, より一層促進さ れ $1 \boldsymbol{\mu m}$ 以下にまで低減していることが分かる．また，SLV 仕様においてもクリアランス減少に伴う起動早期か らのラジアル動圧発生により, 円すいモード系での振れ回り挙動が軽減, すなわち軸振れ回り角度が抑制される ことにより復元モーメントや求心効果に劣る PIN との組合せでも, 特に $Y$ 方向の振れ量を顕著に軸心軌跡の軸振 れが抑制されている。 一方，前報 ${ }^{(5)}$ (P2838の 5.2 項）にて矁案事項となっていた PIN 形状における内周面への 潤滑油流入作用について言及すれば，およそ本作用が充分効果的に働くと思える， $C / d か ゙$ 約 $0.1 \%$ のリアラン ス設定である図 13 （d）PIN-SLVにおいても，他の組合せと比較し軸心軌跡の軸振れが充分に低減されてはいな い. このことから，スラスト動圧形状仕様において，より効果的な軸振れ抑制効果を発揮するのは端面径方向動 圧発生による求心力ではなく, 軸振れ回り角度に対する端面動圧による復元モーメントの大きさであると言える.

ここで, 両クリアランスにおけるリサージュ波形のスラスト動圧形状比較を行うと，HB I 仕様においてはほぼ 同程度，つまりラジアル動圧形状が支配的であり，あまりスラスト動圧形状には依存しない結果と言える。それ に対し，上述のようにSLV 仕様ではスラスト動圧形状に大きく依存し，WAVE形状の方が PIN 形状よりも顕著な 
軸心振れ抑制効果が得られることが判明した。この原因については，前記 5.2 項で述べたことと同様，円すいモ 一ド系における軸振れ回り角度に対し, 端面動圧による復元モーメントが大きく三次元的凹凸部を持つWAVEの 形状的特徵が理由であると考えられるが，さらなる詳細な考察は次項の径方向軸振れ量 $\phi_{w}$ 算出結果に譲るものと する. なお，本軸心軌跡の回転数としては，一般的な DVD ドライブの回転数 $4500 \mathrm{rpm}$ や，2.5 インチおよび 3.5 インチ HDD 回転数規格：5000 7200rpm を参照し，6000rpm 時点のものを代表結果として記載した ${ }^{(13)}$.

\section{$5 \cdot 4$ 径方向軸振れ量 $\phi_{w}$ 算出結果について}

図 14 17 はそれぞれの軸受仕様，ならびにクリアランスにおける軸起動時からの各軸心軌跡より算出した（二 乗和平方根）径方向軸振れ量 $\phi_{w}$ （以降，軸振れ量 $\phi_{w}$ ）の各回転数に対する変化を表している.

まず，図 14 より，C=5 6, ピボット支持での各ラジアル形状の軸振れ量 $\phi_{w}$ を比較すると，アンバランス量によ るラジアル動荷重が増加する 4000rpm 以降において, ラジアル動圧形状仕様と SLV が二分化される結果となり, SLV のみが最大 $6 \mu \mathrm{m}$ 程度で振れ回り状態を呈し軸振れ量が増加する. 回転数全域における軸振れ量 $\phi_{w}$ の順位付

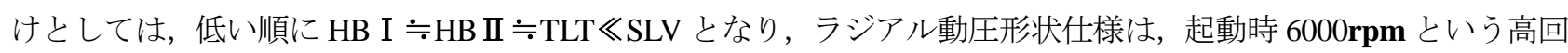
転数時でも, 動圧発生による負荷容量や油膜剛性が得られるため $3 \mu \mathrm{m}$ 程度に軸振れが抑制されている. それに対 LSLV は, 回転数の上昇に伴い増加するラジアル動荷重が支承できるほどの十分な負荷容量や油膜剛性が得られ ないため，軸振れ量 $\phi_{w}$ は著しく増大してくる．ここで，一般的にはアンバランス量による軸振れ量は回転速度の 2 乗に比例し，一方，軸受剛性は回転数の 1 乗に比例することで，最終的に軸振れ量は回転数に比例する傾向に ある.しかしながら，これは軸受内周面に安定して油膜が形成された定常状態においてのことであり，軸振れに 不安定挙動を呈し易い起動時などの非定常状態にそのまま当てはめるにはいささか難がある. 図 14 において, 起 動時の回転数が低い（3000rpm 以下）状態での軸振れ量 $\phi_{w}$ は，動圧形状のない SLV は特に，八ーフホワールな どの不安定現象による並進モード系振れ回りが混在し，4000rpm 以降ではこれが円すいモード系振れ回りが支配 的となることで本実験結果の軸振れ量 $\phi_{w}$ となったものと考える. なお，これについては現在 FFTによる周波数分 析を利用した解析を進めており, 後日改めて報告する予定である. また, 図 10 の 6000rpm 時のリサージュ波形 からも，ラジアル動圧形状仕様である HB I に比べ，SLV が極めて大きな軸心振れ挙動を呈しており，図 $10 （ \mathrm{~b})$ および図 14 の両図から SLV においては軸が円すいモード系で振れ回り状態にあることがよくうかがえる.

一方, 図 15 より $C=3 \sim 4$ におけるピボット支持での各ラジアル形状の軸振れ量 $\phi_{w}$ を比較すると, 起動時の回転 数全域にて軸振れ量 $\phi_{w}$ が低い順に HB I $\fallingdotseq \mathrm{HB} I I \fallingdotseq \mathrm{TLT}<\mathrm{SLV}$ という順位付けとなった．また，C=5 6における測 定結果との比較を行えば, HB I , HB II, TLT の動圧形状仕様では回転数全域にわたって $2 \mu \mathrm{m}$ 程度の良化がみら れ，軸振れ量 $\phi_{w}$ は約 $1.2 \mu \mathrm{m}$ にまで抑制されている. SLVについても全回転数で軸振れ量 $\phi_{w} か ゙$ 減少しており，起動 時 1000 5000rpm で軸振れ量 $\phi_{w}$ は $3 \mu \mathrm{m}$ 程度に低減されている。これは，図 10 (b) と図 11 (b) のリサージュ波 形からも，軸心の振れ回り挙動が軽減されている様子が良くうかがえる. これらの要因としてはクリアランスを

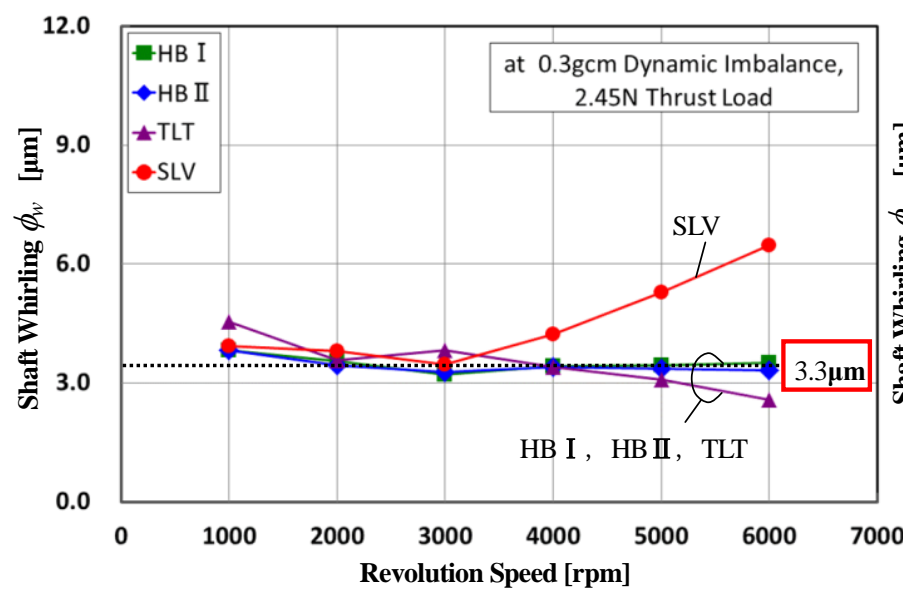

Fig.14 Shaft whirling $\phi_{w}$ vs. Revolution speed ( at Pivot support, @ C=5 6)

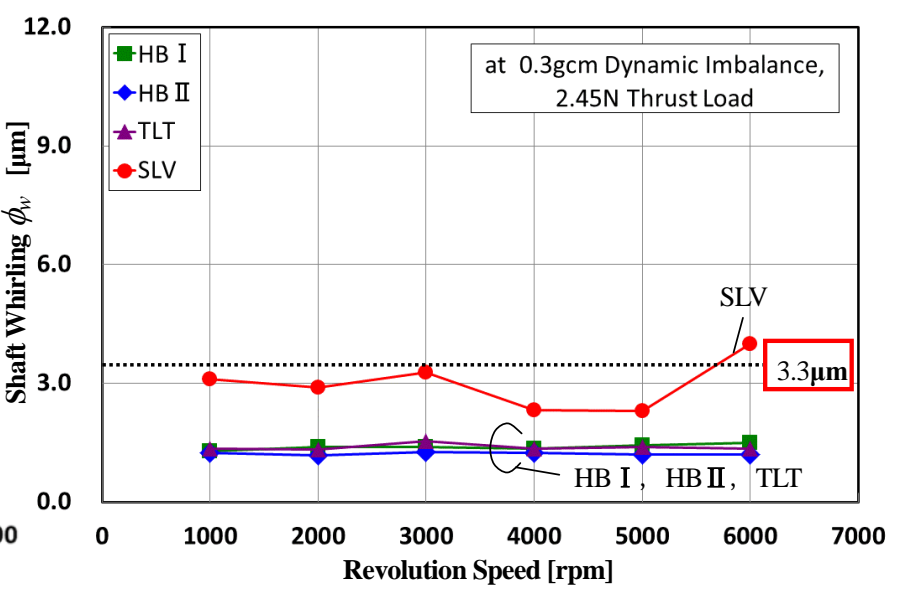

Fig.15 Shaft whirling $\phi_{w}$ vs. Revolution speed ( at Pivot support, @ C=3 4 ) 
減少させたことにより, 軸一軸受間における油膜内圧力が高まり, 負荷容量・油膜剛性の増加が成され軸受内周 面動圧に起因する復元モーメントも高くなるためと推察される. 以上より, 起動時の非定常状態においても $C / d$ を $0.1 \%$ 程度に設定することで，ラジアル動圧形状仕様では，早期の油膜形成と本来の優れた負荷容量・油膜剛 性をより一層高めることができ，動圧発生に乏しいSLVにおいてもラジアル動荷重を支承し得る負荷容量・油膜 剛性をある程度は確保することが可能になると言える.

次に，スラスト動圧形状を付与した複合支持について言及する. まず，図 16 より $C=5 \sim 6$ における複合支持で は，PIN-SLV を除く全仕様にてピボット支持に比較し起動時の軸振れ量 $\phi_{w}$ が一様に低減されていることが分かる （ただし WAVE-SLVの 1000rpm 時のみは例外，この要因の考察こついては前報 ${ }^{(5)}$ を参照されたい)。このときラ ジアル形状に関寸る低軸振れ量の順位付けは，同クリアランスにおけるピボット支持の場合と全く同様（HB I $\mathrm{HB}$ II $\fallingdotseq \mathrm{TLT} \ll \mathrm{SLV})$ となり, ラジアル動圧形状仕様では複合支持とすることで回転数全域にわたり, 約 $0.5 \sim 1.0 \mu \mathrm{m}$ 程度の軸振れ量 $\phi_{w}$ の低減効果が得られる。このことは，図 12 の 6000rpm 時のリサージュ波形において，スラス 卜動圧形状付与により, HB I 仕様は, より小さく安定した軸心振れ挙動を示していることからも良くうかがえる. 一方 SLV 仕様においては, かたやWAVE-SLV は, 起動時の回転数が上昇し端面部分に安定した油膜形成がなさ れると, 前記 WAVE の形状的特徵による端面動圧に起因する復元モーメントの優位性や径方向動圧による求心力, 端面凸部摩擦力が軸振れに対する抑止力として働くことにより，ラジアル動圧形状仕様と同等な軸振れ量 $\phi_{w}$ が達 成される. これに対し, PIN-SLV においては, 前記 WAVE の形状的特徵からくる端面動圧に起因する復元モーメ ントの優位性や径方向動圧などの軸振れ抑制効果はほとんど得られないため, 起動後の回転数全域にてピボット 支持とほぼ同等な軸振れ量 $\phi_{w}$ が計測される。このことは, 図 10 (b) と, 図 12 (c) および (d) のリサージュ波 形からも，軸心振れの状態変化としてよく比較できる.

また図 17 より,クリアランスを $C=3 \sim 4$ に減少させると, 複合支持の全仕様にて約 $1.0 \sim 3.0 \mu \mathrm{m}$ 程度の軸振れ量 $\phi_{w}$ の著しい低減がなされている。このとき軸振れ量 $\phi_{w}$ の各ラジアル形状の順位付けは, 同クリアランスにおける ピボット支持の場合と全く同様（HB I $\mathrm{HB}$ II $\fallingdotseq \mathrm{TLT}<\mathrm{SLV})$ となる. 図より，ラジアル動圧形状仕様ではクリア ランスの減少により, 起動後の回転数全域にわたり軸振れ量 $\phi_{w}$ が約 $1 / 2$ に低減されることが分かる. SLV 仕様に おいても回転数全域にて軸振れ量 $\phi_{w}$ の抑制がなされ, 特に複合支持化ではあまり効果の表れなかった PIN-SLVに おいて, クリアランス減少により 6000rpm における軸振れ量 $\phi_{w}$ は, $C=5 \sim 6$ に対し半滅する結果となった。 これは 図 12 (d) と図 13 （d）のリサージュ波形の比較からも明らかで，クリアランス減少に伴い PIN-SLVにおける軸 心軌跡の軸振れは大幅に改善されている. しかしながら, 改善されたとはいえ依然としてPINに比べWAVEとの 組合せの方が軸振れ量低滅に効果的であることは, 図 17 および図 13 より明白である. 図 17 より, SLV 仕様に おいて起動時 2000rpm, あるいは 4000rpm 以降の軸振れ量 $\phi_{w}$ は, 1.0 1.5 $\mathrm{mm}$ 程度 WAVE との組合せの方が低く， これはスラスト動圧形状における WAVE の形状的特徵からくる端面動圧に起因する復元モーメントの優位性や 径方向動圧による求心力, 端面凸部摩擦力による軸振れ抑制効果がその差となって現れた結果といえる.

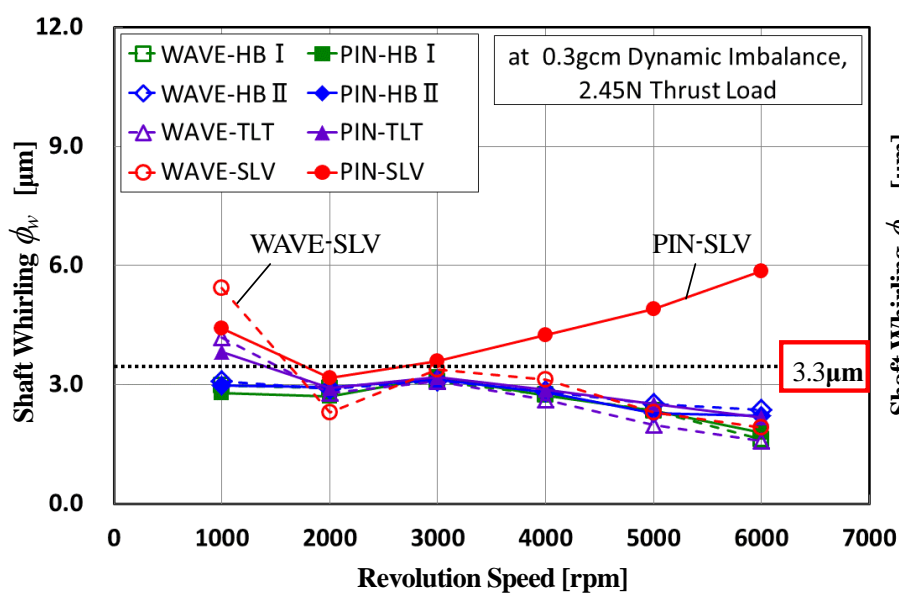

Fig.16 Shaft whirling $\phi_{w}$ vs. Revolution speed ( at coupled bearing, @ $C=5 \sim 6$ )

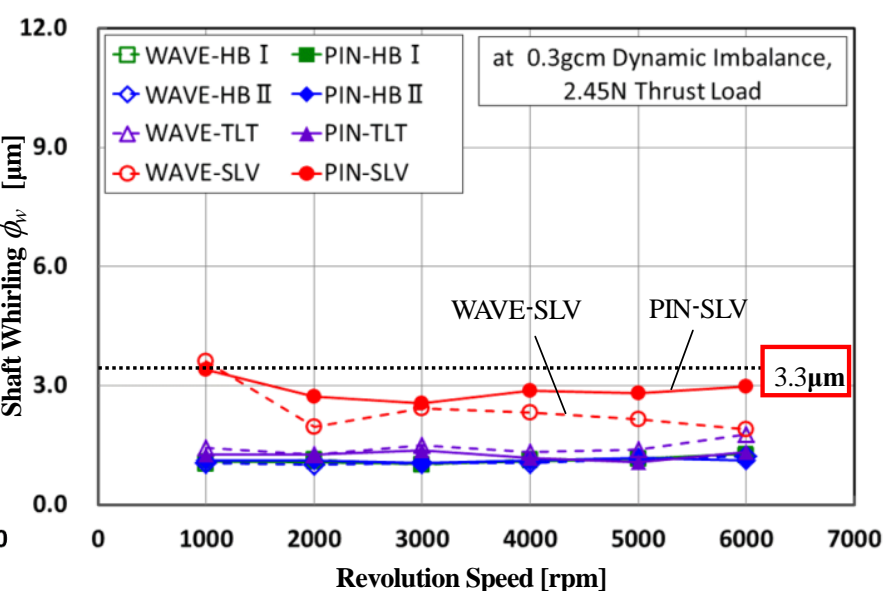

Fig.17 Shaft whirling $\phi_{w}$ vs. Revolution speed ( at coupled bearing, @C=3 4) 
一方，同一クリアランスとして，C=3 4 におけるピボット支持と複合支持の比較を図 15 ，および 17 にて行う

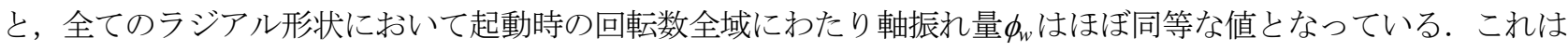
つまり，軸振れ量 $\phi_{w}$ の低減にはクリアランスの減少による効果が支配的であり，複合支持化による効果は副次的 であることを示唆するものである．さらに $C=3 \sim 4$ における複合支持化は，特にラジアル動圧形状仕様において軸 振れ量 $\phi_{w}$ の低減には特段の効果はなく, かえって 5000rpm 以降では僅かながらも悪化の傾向を示す TLT などの 仕様も見受けられる．これは，5.2 項で述べた論旨と同様に，軸径の約 $0.1 \%$ 至るほどのクリアランスの減少と 複合支持化により，潤滑油が過度のせん断応力を受けることで油温が上昇し，油の粘度低下（潤滑油の VI 值に も依存する)による負荷容量や油膜剛性が低減することにより引き起こされた結果であると判断される.加えて, HB に比べ周方向に離散的な 3 つテーパにて負荷容量を賄う TLT では, 必然的に過度のせん断応力による潤滑 油の温度上昇を伴う箇所が限定化されるため軸受全体としての油膜剛性が減じられ，結果として高回転数域にて 軸振れ量 $\phi_{w}$ が若干悪化する傾向になると考えられる.

ここで，2つのスラスト動圧形状による軸振れ量 $\phi_{w}$ の変化について，図 16 を用い SLV 仕様に特化し改めて考 察する. 比較的, 端面摺動部面積（ランド面積）の大きな PIN は, 軸回転初期において摺動面からの含浸油湧出 量が WAVE よりも多いため, 起動と共に動圧が発生し端面への油膜形成が早期になされる．ゆえに 1000rpm の ような低回転数域に限ってはアンバランス量によるラジアル動荷重も小さいため, 上記の早期端面油膜形成によ るPIN の復元モーメント効果が僅かながらも軸振れ抑制に寄与寸ると推察される（表 5,6 の軸振れ最大振幅の 值も参照のこと：いずれの組合せも PIN の方が WAVEより最大振幅が小さい)。しかしながら，回転数が上昇し 両形状の端面部分に安定した油膜形成がなされると, PIN に対し WAVE は上述の形状的特徵からくる端面動圧に 起因する復元モーメントの優位性と, 三次元的凸部の動圧発生による求心力や端面凸部摩擦力が軸振れに対し抑 止力として働き, ラジアル動荷重の増加分を相殺する. これにより結果として, WAVE-SLV はラジアル動圧形状 仕様と同等な軸振れ量 $\phi_{w}$ を達成するのに対し, 端面動圧に起因する復元モーメントに劣る PIN-SLV はピボット支 持 SLV と同様な軸振れ量 $\phi_{w}$ を呈するものと考えられる. 最終的に図 16 および図 12 , もしくは図 17 および図 13 に示寸軸振れ量 $\phi_{w}$ とリサージュ波形より, WAVE-SLV の起動時 6000rpm における軸振れ量 $\phi_{w}$ は, 最大で PIN-SLV の約 1/2 1/3にまで低減されることになる，但し，図 16，および図 17 より，複合支持において WAVE-SLV のク リアランス減少による軸振れ量 $\phi_{w}$ の低減効果はあまり顕著ではない. なぜなら, この WAVE の軸振れ抑制効果は 上記構成上，特に SLV 仕様のような軸受内周面のラジアル動圧効果に乏しく, 且つ回転軸の角度変化が大きい, つまり比較的大きなクリアランスにおいて，またさらに，端面部分の油膜が十分に形成された後に初めて軸振れ 量 $\phi_{w}$ の低減，ならびに安定化を促寸効果として顕著に発揮されるものと考えられるからである.

以上のことから, 図 14 17, および上記考察より, 高精度化における起動時の軸振れ抑制効果に最も優れた動 圧形状の組合せ，ならびにクリアランスは, WAVE-（HB I , HB II, TLT @ C=3 4） のラジアル動圧形状仕様で あると判断される. また, 図 15, 17 の結果より, SLV 仕様を除くラジアル動圧形状仕様では, クリアランスの 軸直径比 $C / d$ を $0.1 \%$ 程度とすることで, どちらのスラスト負荷支持タイプにおいても起動時の回転数全域にわた り, 前記一般的な DVD ドライブのターンテーブル振れ規格 : 10 $\mathrm{um}_{\mathrm{p}-\mathrm{p}}$ （@DVD 最大半径 $60 \mathrm{~mm}$ ）以内に, 実力值 $1 / 2$ 以下という充分な余裕を持って軸振れ量 $\phi_{w}$ が収まる（軸受端面より $20 \mathrm{~mm}$ 位置でターンテーブル振れは $1 / 3$ 倍として換算 : 図中破線の約 $3.3 \mu \mathbf{m}_{\mathrm{p}-\mathrm{p}}$ 以内となる） ${ }^{(13)}$. ちなみに, 図 17 においては, クリアランスの軸直径比 $C / d$ を $0.1 \%$ 程度とし, スラスト動圧形状を付与寸ることでSLV 仕様においてさえも, 上記規格を満足すること が可能となっている. さらに, 寸法公差を含むクリアランスの適正化という観点からみれば, 図 14, 16 のラジア

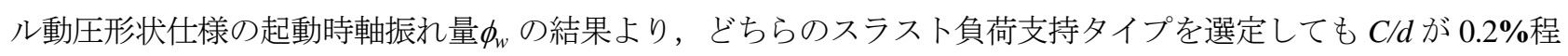
度となるクリアランスが上記ターンテーブル振れ規格を満足できる寸法公差の限界值となることが判明した。 な お，HDD のプラッタ振れ量は各 HDD メーカの一般的規格值が不明のため, この度も DVD ドライブターンテー ブル振れ製品規格を採用し考察を行っている.

\section{6. 結}

以上，軸起動時の非定常状態におけるクリアランスをパラメータとした本実験結果，および考察から以下の点 が明らかになった。 
（1）軸心の早期収束性，および軸振れ抑制に最も効果的な動圧形状の組合せは WAVE-HB I である.

（2）収束時間の順位付けは，早い順に HB I < HB II < TLT 《SLV （ラジアル動圧形状の順位），WAVE < PIN (スラスト動圧形状の順位) であり，軸振れ量 $\phi_{w}$ の低減の順位付けは，HB I $\fallingdotseq \mathrm{HB} I \mathrm{H} \fallingdotseq \mathrm{TLT} \ll \mathrm{SLV}$ (ラジアル動 圧形状の順位)，WAVE《PIN （スラスト動圧形状の順位 @SLV）となる.なお，総じて収束時間の短縮には 端面動圧に起因する復元モーメントが付与される複合支持化が有効であり，軸振れ量低減には $C / d$ を $0.1 \%$ 程 度へ縮小し油膜剛性と軸受内周面動圧に起因する復元モーメントを高める方がより効果的な手段となる.

（3）軸起動直後の軸振れ最大振幅低減に関する順位付けは，両クリアランス，および両スラスト負荷支持 方式共ほぼ同様に HB II $\leqq \mathrm{HB} \mathrm{I}<\mathrm{TLT}<\mathrm{SLV}$ となった．また，ラジアル動圧形状仕様に対する軸振れ最大振幅 の低減には， $C / d$ を $0.1 \%$ 程度へ縮小し油膜剛性と軸受内周面動圧に起因する復元モーメントを高める方法, ならびに複合支持化により端面動圧に起因する復元モーメントを付与する方法共に有効な手段である.

（4）全ての仕様において $C / d$ を $0.1 \%$ 程度とすることで，軸起動時における軸心収束時間の短縮，ならび に軸振れ量 $\phi_{w}$ の低減に著しく効果的である。但し，これを複合支持タイプで実施する場合は，潤滑媒体にかか る過度のせん断応力による温度上昇や軸受寿命への影響を勘案する必要がある.

（5） 特に SLV においては， $C / d$ を $0.1 \%$ 程度とし，さらにスラスト動圧形状との複合支持化することで, 軸振れ量 $\phi_{w}$ が低減され, 軸振れ挙動の安定化が大幅に促進される.

\section{謝辞}

本研究を遂行するにあたり供試軸受などの提供，および試験装置の開発にご協力頂いた日立粉末冶金（株）技 術本部 徳島秀和氏に心よりの感謝を申し上げる.また本研究の一部は平成 24 年度文部科学研究費補助金「基盤 研究 $(\mathrm{C}) 」$ の援助を受けて行われたことを付記して謝意を表する.

\section{文献}

(1) Ohtsuka,S. and Hayakawa,M.,"Experimental Study on the Mechanism of Lubrication in Hydrodynamic Porous Thrust Bearing with a Wavy Surface”, Transactions of the ASME, Journal of Tribology, Vol. 121, July (1999), pp.538-545.

（2）大塚茂，矢壁正樹，柳瀬剛，“多孔質動圧スラスト・ラジアル複合軸受に関する実験的研究”，日本機械学会論文集 C 編, Vol. 70, No.698 (2004), pp.2979-2985.

（3）大塚茂, 矢壁正樹, 大塚宏一, 柳瀬岡川, “多孔質動圧スラスト・ラジアル複合軸受における潤滑特性の実験的研究”, 日 本機械学会論文集 C 編, Vol. 74, No.737 (2008), pp.174-182.

(4) Kobayashi,T. and Yabe,H., "Numerical Analysis of a Coupled Porous Journal and Thrust Bearing System” , Transactions of the ASME, Journal of Tribology, Vol. 127, January (2005), pp.120-129.

（5）大塚茂, 矢壁正樹, 権田岳, 徳島秀和, “多孔質動圧スラスト・ラジアル複合軸受における非定常時潤滑特性の実験的 研究”，日本機械学会論文集 C 編, Vol. 77, No.779 (2011), pp.2832-2841.

（6）平山朋子，佐海真吾，山口奈緒美，菱田典明，矢部寛,“精密機器スピンドル用スパイラル溝付ジャーナル軸受の 溝諸元の最適化に関する一考察”, 日本機械学会論文集 C 編,Vol. 72, No.713 (2006), pp.241-246.

（7）朱加生，小野京右, “磁気ディスクスピンドル用各種油潤滑スラスト軸受に関する特性比較研究”, 日本機械学会 論文集 C 編, Vol.64, No.624 (1998), pp.3155-3162.

（8）小野京右, 朱加生, “磁気ディスクスピンドル用各種油軸受に関する特性比較研究”, 日本機械学会論文集 C 編, Vol.64, No.622 (1998), pp.2205-2211.

（9）十合晋一著，気体軸受，初版 3 刷 (1992), pp.44-52，共立出版株式会社.

（10）十合晋一著，気体軸受設計ガイドブック，初版 1 刷 (2002), pp.99-127，共立出版株式会社.

(11) E.A.Muijderman, Spiral Groove Bearings, (1966), pp.62-99, Philips tech. Lib.

(12) V.T.Morgan, "Porous Metal Bearings", Transactions of the EPME, Powder Metallurgy, Vol.12, No.24 (1969), pp.426-451.

（13）沖永欽二郎，安藤明夫，益田久光男，藤中広康，“DVD レコーダ用スピンドルモータ”，松下テクニカルジャーナ ル,Vol.51 No.1 Feb. (2005), pp.52-55. 